\title{
Malay Heritage Houses Design via the Principle of "Form Follows Function" by Louis Sullivan
}

\author{
Azreena Abu Bakar, Kamarul Afizi Kosman, Nor Zalina Harun
}

\begin{abstract}
The uniqueness of the Malay heritage house architecture lies in the diversity of carving forms of various motifs. The motif was chosen based on the image of the environment at the time. This paper discusses the selection of carving motifs in Malay houses based on the principle of form follows function introduced by a Western architect Louis Sullivan in the late 19th century. The meaning of form follows function in this study refers to the selection of the shape of a carving motif adjusted according to the function of the space in the Malay heritage house. A preliminary study was conducted on 10 Malay heritage houses in Peninsular Malaysia built in the 1800s. It aimed to get the types of commonly used motifs during the century of the principle was introduced. The selected houses were located in 10 states in Peninsular Malaysia obtained from measured drawings from the Center for the Study of Built Environment in The Malay World (KALAM) in Universiti Teknologi Malaysia (UTM). The selected houses were based on the most widely used carving motifs. For the purpose of this study, three houses were selected from the initial 10 houses to be further analyzed and mapped in terms of shape and placement of carving motifs based on the principle of form follows function. The study focused on the carving motifs in serambi and rumah ibu of the Malay heritage house as these two spaces had the most carving motifs. The mapping of the motifs in the two spaces shows four main motifs of flora, fauna, geometry, and calligraphy. The motifs of each home will be described from the angle of symbolism, layout, and carving style that can describe the principle of form follows function.
\end{abstract}

Keywords: Carving motif, form follows function, Malay heritage house, rumah ibu, serambi.

\section{INTRODUCTION}

The Malay heritage houses are synonymous with beautiful carving motifs. Its layout is well-balanced and soothing to the eye. In addition, its interior and exterior layout are also designed to suit the activities of the occupants and the environment. Multiple openings allow for natural ventilation and lighting to make the Malay heritage house feel cool and comfortable when occupied. These characteristics describe the identity of Malay architecture that should be emulated in terms of architectural design which are territorial, which gives a sense of belonging to the occupants. However, the current architectural designs, primarily housing, is facing various problems such as inefficient space arrangements that cause privacy discomfort, hot house conditions, and Western-style houses. According to Louis Sullivan, a

Revised Version Manuscript Received on September 16, 2019.

Azreena Abu Bakar, Centre for Innovative Architecture and Built Environment, Faculty of Engineering and Built Environment, Universiti Kebangsaan Malaysia, Bangi, Selangor, Malaysia.

Kamarul Afizi Kosman, Centre for Innovative Architecture and Built Environment, Faculty of Engineering and Built Environment, Universiti Kebangsaan Malaysia, Bangi, Selangor, Malaysia.

Nor Zalina Harun, Institute of The Malay World and Civilisation (ATMA), Universiti Kebangsaan Malaysia, Bangi, Selangor, Malaysia
Western architect, a successful architecture should be based on the principle of form follows function that is the disclosure of space function. This principle is well received in Europe in the early 20th century due to regionalism where environmental factors were viewed to provide comfort to the occupants. For that reason, this study aimed to assess and map the principles set out by Louis Sullivan at the end of the 19th century to the placement and selection of motifs in spaces in the Malay heritage houses. The objective of this study was to identify and map the characteristics found in the Malay heritage houses based on the principle of form follows function which is in line with the principle introduced by Louis Sullivan.

\section{LITERATURE REVIEW}

\section{Malay heritage house}

The Malays in this country are from different tribes. This caused the Malay heritage houses to have their own distinctive features. The materials used for the houses were fully acquired from the surrounding area using local energy and technology. According to [1], a basic traditional Malay house have a verandah (selasar or serambi), a main room (rumah ibu) containing a sleeping area and the kitchen (dapur) at the back of the house as shown in Fig. 1).

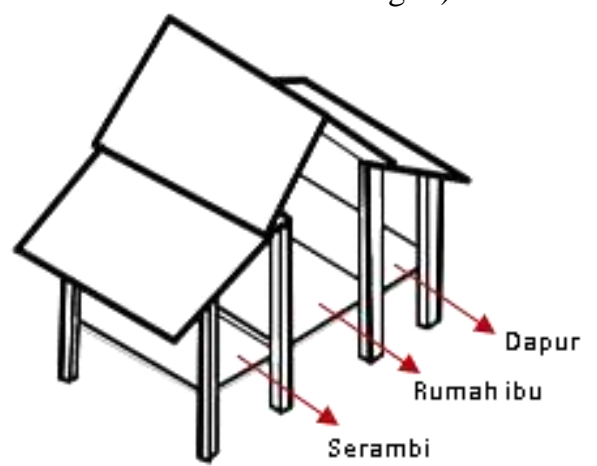

Fig. 1: Basic traditional Malay house layout

A basic house consists of four-column house with four-sided wall, but according to [2], the construction of the earliest Malay heritage houses is a 6-column house. When a family becomes big, a spacious room is needed to accommodate the whole family and that yielded a 12-column house. Fig. 2 shows the evolution of Malay house from a primitive form to a more complex form [3].

Published By:

Blue Eyes Intelligence Engineering

\& Sciences Publication 

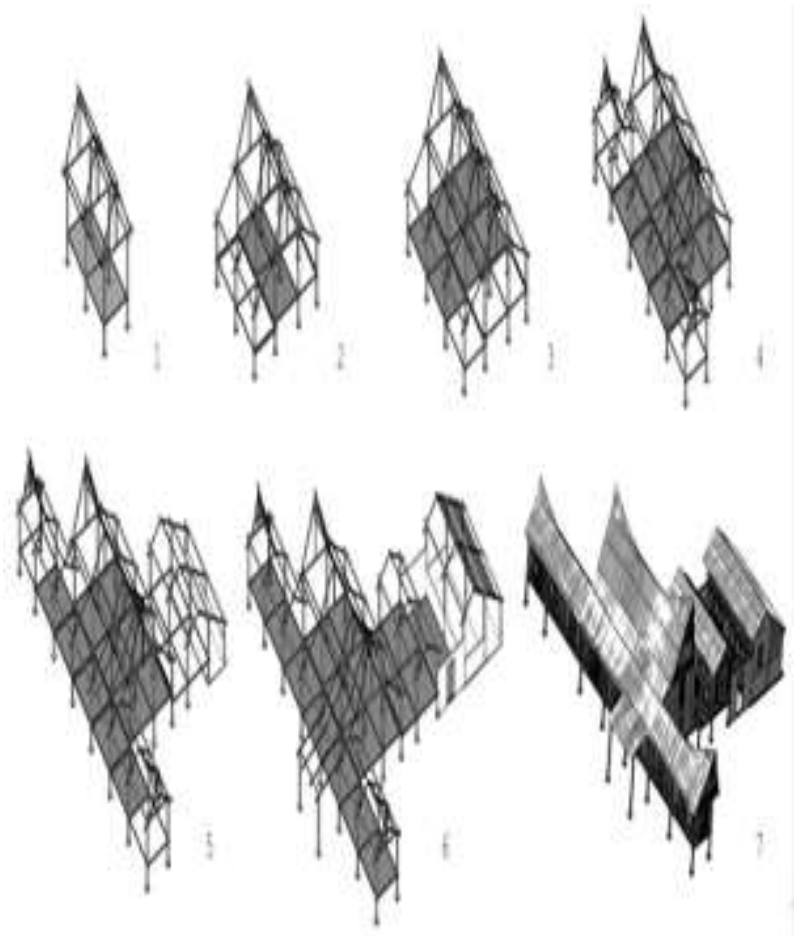

Fig. 2: Evolution of Malay heritage house Space and function

There are 6 spaces in the Malay heritage house which are anjung, serambi, rumah ibu, selang, dapur, and pelantar. Not all houses have the 6 spaces but three main compulsory spaces are serambi, rumah ibu, and dapur. The function of each space is different depending on the activity of the occupants of the house. According to [4], he noted that the creation of spaces in Malay heritage houses is closely related to human activities, limitations, and work space such as tools and furniture. The activities in each of these spaces are listed in Table 1.

Table 1: Compulsory three main spaces in Malay heritage house and their respective activities and users

\begin{tabular}{|c|c|c|}
\hline Space & Human Activities & Main User \\
\hline $\begin{array}{l}\text { Serambi } \\
\text { - Public }\end{array}$ & $\begin{array}{l}\text { - Greet guest } \\
\text { - Circulation } \\
\text { - Eating } \\
\text { - Entertainment } \\
\text { - Sleeping } \\
\text { - Formal occasion } \\
\text { - Meeting/discussi } \\
\text { on }\end{array}$ & Men \\
\hline $\begin{array}{l}\text { Rumah ibu } \\
\text { - Semipub } \\
\text { lic }\end{array}$ & $\begin{array}{l}\text { - Circulation } \\
\text { - Receiving house } \\
\text { guest } \\
\text { - Eating } \\
\text { - Family gathering } \\
\text { - Sleeping } \\
\text { - Working } \\
\text { - Praying }\end{array}$ & $\begin{array}{l}\text { Family } \\
\text { members }\end{array}$ \\
\hline $\begin{array}{l}\text { Dapur } \\
\text { - Private }\end{array}$ & $\begin{array}{l}\text { - Cleaning } \\
\text { - Cooking } \\
\text { - Storage } \\
\end{array}$ & Women \\
\hline
\end{tabular}

Carving on house

In general, carving plays an important role in enhancing the features of a house, as well as functioning as ventilation and lighting holes. Carving is also one of the branches of Malay art which combines the beauty, value, function, and creative expression of an artist [5]. Carving is so synonymous with Malay heritage houses that is has to be placed on the roof like louvered screen (tebar layar) and fascia board (papan cantik), on the wall as partitions such as ventilation panel on top of windows and doors, on the stairs and on the column. In addition to aesthetic element, carving also has meaning or symbol associated with the concept of nature and divinity through the selection of certain motifs.

\section{Carving style selection}

Malay woodcarving is comprises various techniques such as direct piercing (tebuk terus), semi piercing (tebuk separuh) and emboss piercing (tebuk timbul) [6]. All techniques can be done with or without 3D incision (silat). Each carving style has functions customizable based on space. According to [7], in addition to being a beauty element, direct piercing (tebuk tembus) carving style allows lighting into the house at night, producing a silhouette in the interior space that accentuates its beauty. The placement of this carving motif is often found in the main hall of the Malay heritage house, which is on serambi, rumah ibu, and dapur.

The selection of carving style and motif also affects a space. For example, the direct piercing with 3D incision style fits in rumah ibu or serambi as it is more beautiful and soft. The placement the style perfectly suited rumah ibu or serambi as an allurement. In addition, the hollow carving makes its suitable to be used as ventilation panel mounted on top of windows and doors which allows ventilation and lighting to go directly into the house.

The direct piercing (tebuk tembus) style has a rather hard and stiff feature. This carving style is best placed in the kitchen area as the kitchen is a less-functional place in terms of human activities compared to the activities in serambi and rumah ibu. Furthermore, the kitchen area is located at the back of the house and is a private space for women. Hence, the direct piercing (tebuk tembus) style is suitable to be placed here because it does not function to attract attention, but serve as ventilation and lighting vent when cooking and washing.

The emboss carving (ukiran timbul) style includes with and without $3 \mathrm{D}$ incision. It is often placed at the interior part of the house as in the upper part of a separating wall or above the room door.

\section{Selection of the form of motif}

The selection of carving motif affects the function of a space. According to [8], these motifs were based on the beliefs and daily life they were experiencing which inspired many Malays. It was also stated that there was an assumption that the adoption of carving motifs which symbolized folk games such as cockfighting (Ayam Berlaga), bird fighting (beradu burung), and fish fighting (berlaga ikan) could bring sustenance. For the Malays, carving motif has its own implicit meaning. 
Typically, the carvings in these main spaces have different motifs because each motif needs to be adjusted to the function of the space. For example, the serambi space is the space for men and one of the activities that takes place in such spaces is discussion. Therefore, the motifs that fit men that depict leadership should be highlighted. Among the motifs suitable for men especially in the serambi space are fauna motifs such as Semut Beriring motif. This motif symbolizes leadership and cooperation based on the attitude and character of the animal that need to be emulated to maintain harmony.

For a more spacious serambi for family activities, the appropriate motif placed in the space is a floral-shaped motif such as bamboo shoots that means to progress and do not collapse because of the nature of this plant that grows vertically and difficult to fall. It is intended for family members not to despair and always move forward.

The kitchen space is more associated with cooking activities dominated by women. Geometric motifs are chosen as ventilation panel at the top of this space wall which serves as an opening for air and lighting. Usually this motif does not give any meaning because the kitchen space is not a space for use and public viewing. The aesthetic value of this space is limited. All clarifications about the form of motif and space functions explain that the design of the Malay heritage house architecture is in accordance with the principle of form follows function with the form of a motif is chosen according to the suitability of the space function in terms of activity.

The principle of form follows function by Louis Sullivan

A Western architect Louis Sullivan has introduced the principle of form follows function in the end of the 19th century in Europe. This principle has become a trend and began to flourish in the early 20th century. According to him, the shape of a structure is determined by its function and not just the decoration. Ornaments used should be from nature and not from the past architectures. Building materials used are also in accordance with time.

This approach is similar to the approach used in the Malay heritage houses that use building materials and motifs based on the environment. The spaces found in Malay heritage houses depended on the sociocultural activities at that time. One of his most frequently-referred building is the Wainwright building in Fig. 3.

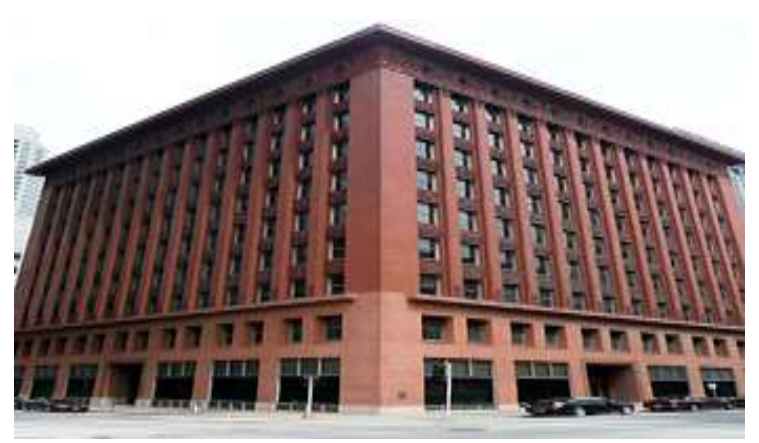

Fig. 3: Wainwright building at USA

Louis Sullivan and his colleague Adler were the first architects to use steel as the building structure to replace bricks. The pillars of the building were also decorated with flora-based ornaments in Fig. 4.

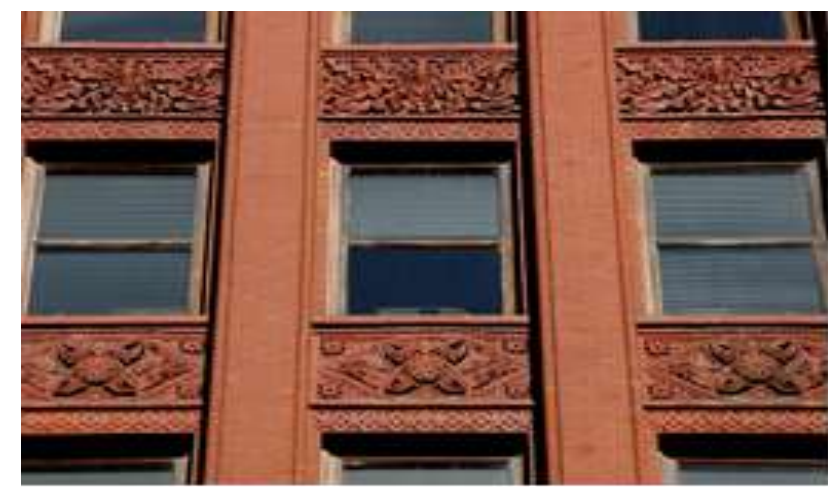

Fig. 4: The use of flora and fauna ornaments on Wainwright buildings

The design of this Wainwright building was inspired from the environment such as the use of terra cotta which is a popular building material at that time. He was aware of the contemporary function and technology. The use of foliated decorative motif contained within the geometric frames also adorned the pillars and facade of the building. The squared-shape building has many windows openings suited the functionality of an office that requires a lot of lighting and practical space. The use of current technology such as steel as the main structure of buildings replacing bricks is seen as the acceptance of new things over time. All of the approaches highlighted in this building are more characterized by regionalism, the architecture of which has the character or identity of a place. Therefore, this study aims to evaluate and map the principles set forth by Louis Sullivan in the late 19th century on the placement and selection of carving motifs on the Malay heritage house spaces.

\section{METHODOLOGY}

Exploration was chosen as the methodology in this study by taking the major sources of measured drawings and reports from the Center for the Study of Built Environment in The Malay World (KALAM) in Universiti Teknologi Malaysia (UTM). A total of 10 Malay heritage houses located in 10 states, namely Negeri Sembilan, Kelantan, Terengganu, Pahang, Perlis, Melaka, Johor, Perak, Penang, and Kuala Lumpur were used in the preliminary study. The houses were selected based on the most exhibited carving motifs in serambi and rumah ibu and the year of built in around the 19th century. Serambi and rumah ibu were chosen because these two spaces had the most functions compared to other spaces. This initial study is important to obtain the types of carving motifs found in these two spaces to be mapped to the next study. As a result of the initial study, three houses were later selected for analysis and mapping in terms of shape and placement of carving motifs based on the principle of form follows function. The data obtained from KALAM is very important to prove the results obtained from the analytical 
study of measured drawings.

\section{Analytical review and archived documents}

\section{Initial study}

An analytical preliminary study was carried out on 10 Malay heritage houses located in Negeri Sembilan, Kelantan, Terengganu, Pahang, Perlis, Melaka, Johor, Perak, Penang, and Kuala Lumpur. This Malay heritage houses dated back to the 1850s and 1930s. This kind of house was no longer constructed after the Second World War and was regarded as a traditional Malay architectural heritage [9]. Therefore, the houses were believed to be built without any external influence. The information about the houses which include owner, location, and year of built are shown in Table 2 .

Table 2: Ten Malay heritage houses selected for preliminary study

\begin{tabular}{|l|l|l|}
\hline \multicolumn{1}{|c|}{ N } & House Owner & State \\
\hline 1 & Tok Ku Paloh & Terengganu \\
\hline 2 & Posah Sawal & Negeri Sembilan \\
\hline 3 & Che Sidik & Kelantan \\
\hline 4 & Tuan Wasim Umi & Johor \\
\hline 5 & Esah Abdullah & Kuala Lumpur \\
\hline 6 & Abdul Rahim Ahmad & Melaka \\
\hline 7 & Sheikh Osman & Pulau Pinang \\
\hline 8 & Penghulu Ismail Jasin & Perlis \\
\hline 9 & Mohd. Dahan & Pahang \\
\hline 10 & Kutai Sahak & Perak \\
\hline
\end{tabular}

Types of carving motifs at serambi and rumah ibu

Four types of carving motifs that decorated serambi and rumah ibu were observed that are flora, fauna, geometry, and calligraphy as shown at Table 3 .

Table 3: Carving motif analysis found in 10 Malay houses

\begin{tabular}{|c|c|c|c|c|}
\hline \multirow[t]{2}{*}{ No } & \multirow{2}{*}{$\begin{array}{l}\text { House } \\
\text { Owner }\end{array}$} & \multirow[t]{2}{*}{ State } & \multicolumn{2}{|c|}{ Types of Carving Motif } \\
\hline & & & Serambi & Rumah Ibu \\
\hline 1 & $\begin{array}{c}\text { Tok } \\
\text { Ku Paloh }\end{array}$ & $\begin{array}{ll} & \text { Terenggan } \\
\mathrm{u} & \end{array}$ & None & $\begin{array}{l}\text { Flora and } \\
\text { Fauna }\end{array}$ \\
\hline 2 & $\begin{array}{l}\text { Posah } \\
\text { Sawal }\end{array}$ & $\begin{array}{l}\text { Negeri } \\
\text { Sembilan }\end{array}$ & $\begin{array}{l}\text { Geometry } \\
\text { and Fauna }\end{array}$ & Geometry \\
\hline 3 & $\begin{array}{l}\text { Che } \\
\text { Sidik }\end{array}$ & Kelantan & None & $\begin{array}{c}\text { Flora and } \\
\text { Calligraphy }\end{array}$ \\
\hline 4 & $\begin{array}{l}\text { Tuan } \\
\text { Wasim } \\
\text { Umi }\end{array}$ & Johor & Fauna & Fauna \\
\hline 5 & $\begin{array}{c}\text { Esah } \\
\text { Abdullah }\end{array}$ & $\begin{array}{l}\text { Kuala } \\
\text { Lumpur }\end{array}$ & Geometry & $\begin{array}{c}\text { Flora and } \\
\text { Geometry }\end{array}$ \\
\hline 6 & $\begin{array}{l}\text { Abdul } \\
\text { Rahim } \\
\text { Ahmad }\end{array}$ & Melaka & Flora & $\begin{array}{c}\text { Flora and } \\
\text { Geometry }\end{array}$ \\
\hline 7 & $\begin{array}{r}\text { Sheik } \\
\text { h Osman }\end{array}$ & $\begin{array}{l}\text { Pulau } \\
\text { Pinang }\end{array}$ & Geometry & $\begin{array}{c}\text { Flora and } \\
\text { Geometry }\end{array}$ \\
\hline 8 & \begin{tabular}{l}
\multicolumn{1}{c}{ Pengh } \\
ulu Ismail \\
Jasin \\
\end{tabular} & Perlis & Geometry & $\begin{array}{c}\text { Flora and } \\
\text { Geometry }\end{array}$ \\
\hline 9 & $\begin{array}{l}\text { Mohd. } \\
\text { Dahan }\end{array}$ & Pahang & Geometry & Flora \\
\hline 10 & $\begin{array}{l}\text { Kutai } \\
\text { Sahak }\end{array}$ & Perak & \begin{tabular}{l}
\multicolumn{1}{c}{ Flora, } \\
Fauna and \\
Geometry
\end{tabular} & \begin{tabular}{l}
\multicolumn{1}{c}{ Flora, } \\
Fauna and \\
Geometry
\end{tabular} \\
\hline
\end{tabular}

\section{Case study}

Based on the result of the preliminary study, only three houses were selected as case studies to illustrate the principle of form follows function. The chosen houses were the house of Tok Ku Paloh, the house of Posah Sawal, and the house of
Che Sidik (Table 4). The three houses were selected because each house has different home and motif functions and can also portray the principle of form follows function more precisely. In addition, 4 factors were chosen in selecting the houses namely (1) type of carving motif, (2) symbolism, (3) layout, and (4) carving style in serambi and rumah ibu.

Table 4: The selected three houses

\begin{tabular}{|c|c|c|c|c|c|}
\hline $\mathrm{Na}$ & Ouner & Location & Home Function & $\begin{array}{l}\text { Space } \\
\text { Studied }\end{array}$ & Motif \\
\hline 1 & $\begin{array}{l}\text { Tok Kn } \\
\text { Pabh }\end{array}$ & $\begin{array}{c}\text { D62, Makam TokKu, } \\
\text { Cabang } \\
\text { Tiga, Kuala } \\
\text { Terengganu }\end{array}$ & $\begin{array}{c}\text { Islamic leaming } \\
\text { center }\end{array}$ & Rumah ibn & Flon \\
\hline 2 & $\begin{array}{l}\text { Sawah } \\
\text { Sawal }\end{array}$ & $\begin{array}{l}\text { 32, Kampung Parit } \\
\text { Seberang, } \\
\text { Kuala Pilah, Negeri } \\
\text { Sembilan }\end{array}$ & Personal house & Serambi & Fauna \\
\hline 3 & Che Sidik & $\begin{array}{c}\text { Kampung Penambang, } \\
\text { Kota } \\
\text { Bharr, Kelantan }\end{array}$ & $\begin{array}{c}\text { Songhet desler } \\
\text { house }\end{array}$ & Rumah ibu & $\begin{array}{c}\text { Calligrap } \\
\text { hy }\end{array}$ \\
\hline
\end{tabular}

\section{RESULTS AND DISCUSSION}

The carving motifs in every Malay house have various forms. According to [10], the selection of motifs in Malay carvings has elements related to social interactions that refer to the activities that occur in the space. Carving motifs of flora, fauna, geometry, and calligraphy are among the most popular motifs found in Malay heritage houses compared to the other motifs. Only three motifs were selected for this study: flora, fauna, and calligraphy as these three motifs were often exhibited in serambi and rumah ibu. According to [11], Latif Long stated that there are three reasons of choosing a motive in terms of (1) its properties, (2) beauty and fragrance of its flower, and (3) the uniqueness of the shape of its flower and leaf. The fauna motif was chosen based on animal characters that can be inspired as a symbol. For calligraphy motifs, the selection of surah is about protection, sustenance, grace, forgiveness, and glory.

The house of Tok Ku Paloh

\section{Motif type - Flora}

The house of Tok Ku Paloh was located in Terengganu and was a center of Islamic studies. The house had three flora motifs:

- Daun Sayap,

- Daun Bayam, and

- Bunga Cempaka.

The placement of the flora motif is shown in Fig. 5. The flora motif was chosen because it has its own specialty, especially in medicine.

\section{Symbolisme}

The Daun Bayam (Spinach) motif was chosen because of its excellent properties in eye care and symbolizes reminders to the occupants. Eyes are an important element in learning process, so the Daun Bayam motif was embellished as a 
reminder for its nutritional value especially for students.

The Daun Sayap motif was chosen to decorate the house because of its efficacy in the treatment of mild wounds. Normally, the home school consists of young playful people that sometimes leads to minor body injuries. Therefore, the choice of the Daun Sayap motif is the best reminder of its healing properties.

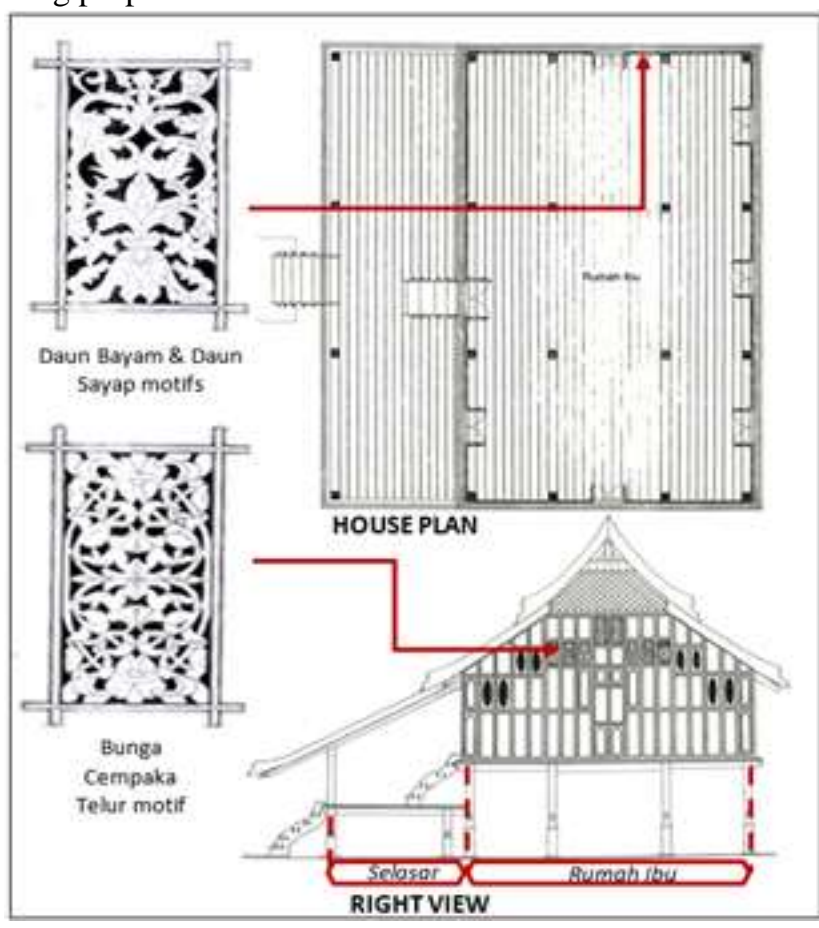

Fig. 5: The use of flora motif at the House of Tok Ku Paloh, Terengganu

Gardenias (Cempaka) are known for their fragrance. In learning, fragrant scents are one of the elements that can stimulate a sharp mind. Therefore, the Bunga Cempaka motif was chosen as it can help stimulate the mind of young people to memorize faster.

\section{Layouts}

The layout of all these flora motifs is in ventilation panel in rumah ibu as shown in Fig. 4. This shows that the rumah ibu is an important activity space as it functions as a study room. Therefore, placing the motifs on the upper part of rumah ibu is most appropriate so that itcan be seen by the young people as well as to remind the benefits of the flora motifs.

\section{Carving style}

The type of carving style on all these floral motifs is direct piercing with 3D incision (tebuk tembus bersilat). This carving style was chosen to get a comfortable atmosphere during a learning process that facilitates airflow and lighting directly into rumah ibu.

\section{The house of Posah Sawal}

\section{Motif type - Fauna}

The fauna motifs are based on animal form. Before the advent of Islam, many sculptures used the motifs of living forms such as humans and animals. But after the arrival of Islam to Malaya, the form of animate thing is prohibited. Therefore, the form of animal carving has been stylized so as not to resemble the real figure of the animal, so it is possible that the fauna motifs take basic features only. Animal selection is also based on the nature or character of the animal that symbolizes the spirit and the strength to serve as an example. The house of Posah Sawal in Negeri Sembilan is one of the houses that used the fauna motif (Fig. 6).

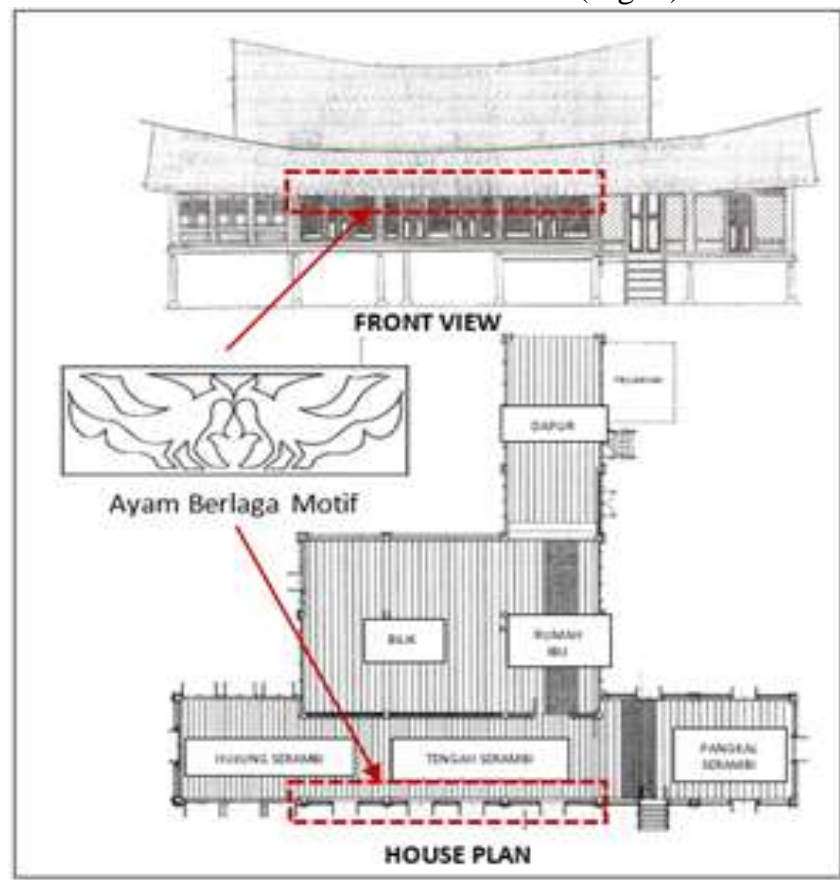

Fig. 6: The Ayam Berlaga (cockfighting) motif on the window in the central serambi space in Posah Sawal's house in Negeri Sembilan

\section{Symbolisme}

The Ayam Berlaga (cockfighting) motif can be seen at the top of the window at the center of serambi. This motif actually symbolizes the character of fighting roosters and this action has two meanings that are the roosters are (1) in power, guarding the area and (2) as an example not to become like fighting roosters. The target group is the children and the people who are meeting in serambi because the attitude of children who often fight and it needs to be emphasized via moral values. The guarding nature of roosters also gives an example to the occupants to keep manners among each other to avoid such quarrels or conflicts.

\section{Layouts}

This layout of this fauna motif is at the top of the central serambi facing the open space. Serambi is always a place to relax for meetings and discussions. Children will usually play around at the front of the house and will always see this motif while playing because the spaces are facing each other so the Ayam Berlaga motif will always remind them of its meaning. This motif also warns those involved with the activities of the meeting to keep the manners to achieve harmony so as not to be like roosters fighting.

\section{Carving style}

The carving style for the Ayam Berlaga motif is direct piercing without 3D incision (tebuk tembus tanpa silat). It permits airflow directly into the house when all openings 
such as windows and doors are closed at night.

\section{The house of Che Sidik}

\section{Motif type - Calligraphy}

Calligraphy motifs are taken from Quranic verses and are used by carvers after the Malays accept Islam as their life. This motif is best suited as a carved decorative panel as a reminder to the person who sees it as shown at Fig. 7.

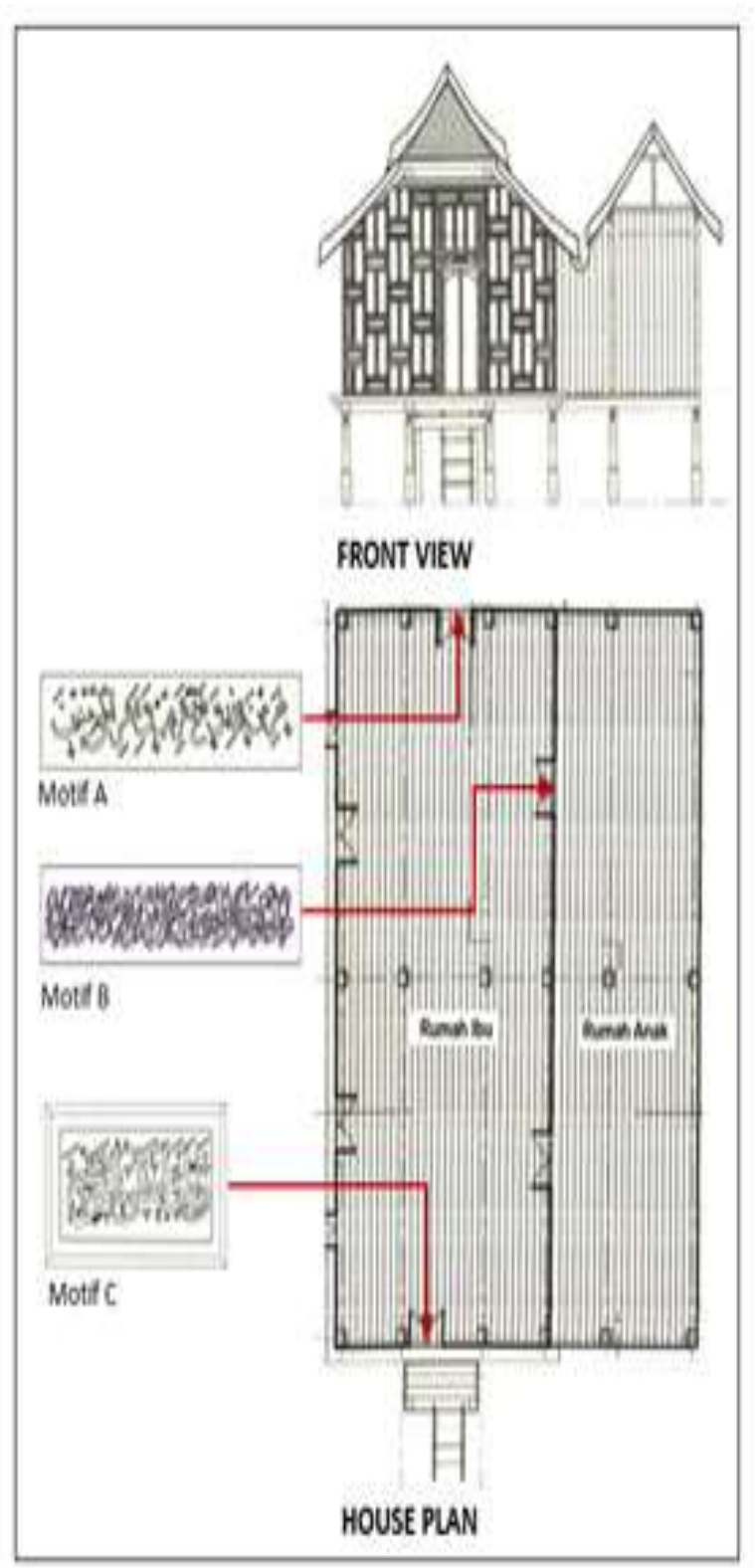

Fig. 7: The use of calligraphy motif at Che Sidik's house in Kota Bharu, Kelantan

Calligraphy motifs are sometimes mixed with fauna motifs to accentuate their beauty. Usually Islamic artists will choose the verses that correspond to the message. Obviously, Islamic art not only contains aesthetic value but also contains a distinctive and profound intellectual value [12].

\section{Symbolisme}

Calligraphy motifs symbolize spiritual. The Holy Spirit is greatly emphasized in religion because the spiritual of every individual is a social determinant of a society. Reciting the Quran and practicing the teachings of the Quran are the acts of heart cleansing. Therefore, most calligraphy motifs are derived from surahs in the Quran for heart cleansing and the complete code of life.

There are five basic principles in choosing surah to be used as a calligraphic motif that deals with protection, sustenance, grace, forgiveness, and glory. Usually this spiritual motif layout is placed on top to keep its purity and be easily seen as at the top of a door and ventilation panel.

This house was owned by a famous songket businessman in Kelantan. The work of songket weaving is done at the home whereas rumah ibu is used for resting. It is believed that the occupants of the house relied heavily on Islamic religious beliefs in their daily lives as the calligraphy motives seen contain Quranic verses and exemplary stories for guidance.

Motif $\mathrm{A}$ is a verse taken from surah as-Saf (61:13) which means "And [you will obtain] another [favor] that you love victory from Allah and an imminent conquest; and give good tidings to the believers". This verse was chosen so that the occupants can read and practice it always to receive the blessings or sustenance from Allah SWT.

Motif B is the names of the seven young men mentioned in the story of Ashabul Kahfi. These names were chosen as exemplary reminder and illustrate the glory of God given to His devoted servants.

Motif C is a verse taken from surah al-Qalam (68:4) which means "And indeed, you are of a great moral character." This verse was chosen as an encouragement to emulate such noble character as the Messenger of Allah (peace be upon him).

\section{Layouts}

All the placements of calligraphy motifs at Che Sidik's house is on top of the door in rumah ibu. This shows that rumah ibu was often used and suitable to be used for any religious activities. While functioning as a resting space, rumah ibu is the ideal place to enjoy the beauty of calligraphy motifs as well as to memorize the verse unknowingly. In addition, it reminded them of exemplary stories.

\section{Carving style}

The carving style of this calligraphy motif is direct piercing without 3D incision (tebuk tembus tanpa silat) and placed on top of the door of rumah ibu.

The findings show that the Malay heritage houses used the principle of form follows function with the motif placements were chosen according to the function of the space and owner's background. Table 5 shows the relationship between the shape and function of the space of the Malay heritage house. This principle was introduced in the end of the 19th century (around the 1870s) and the studied Malay heritage houses were built in the early 19 th century. 
International Journal of Recent Technology and Engineering (IJRTE)

ISSN: 2277-3878, Volume-8, Issue-2S11, September 2019

Table 5: Relationships between the form and function that resulted in other purposes in the principle of form follows function

\begin{tabular}{|c|c|c|c|c|c|c|c|c|c|}
\hline \multirow{2}{*}{\multicolumn{2}{|c|}{ House/Owner }} & \multicolumn{3}{|c|}{ Function } & \multicolumn{3}{|c|}{ Design } & \multicolumn{2}{|c|}{ Symbolism } \\
\hline & & & & & & & & & \\
\hline 1 & $\begin{array}{c}\text { Tok Ku } \\
\text { Paloh }\end{array}$ & $\begin{array}{l}\text { Islamic } \\
\text { learning } \\
\text { center }\end{array}$ & $\begin{array}{c}\text { Learning, } \\
\text { resting }\end{array}$ & $\begin{array}{c}\text { Rumah } \\
\text { ibu }\end{array}$ & Flora & $\begin{array}{c}\text { Ventilation } \\
\text { panel on wall }\end{array}$ & $\begin{array}{c}\text { direct } \\
\text { piercing with } \\
\text { 3D incision } \\
\text { (tebuk } \\
\text { tembus } \\
\text { bersilat) }\end{array}$ & $\begin{array}{c}\text { Medicinal } \\
\text { and } \\
\text { nutritional } \\
\text { benefits }\end{array}$ & Reminder \\
\hline 2 & $\begin{array}{l}\text { Posah } \\
\text { Sawal }\end{array}$ & $\begin{array}{c}\text { Personal } \\
\text { house }\end{array}$ & $\begin{array}{l}\text { Meetings, } \\
\text { discussion }\end{array}$ & Serambi & $\begin{array}{c}\text { Faun } \\
\mathbf{a}\end{array}$ & $\begin{array}{l}\text { Ventilation } \\
\text { panel on top } \\
\text { of windows }\end{array}$ & $\begin{array}{c}\text { direct } \\
\text { piercing } \\
\text { without 3D } \\
\text { incision } \\
\text { (tebuk } \\
\text { tembus tanpa } \\
\text { silat) } \\
\end{array}$ & $\begin{array}{l}\text { Moral } \\
\text { values }\end{array}$ & Exemplary \\
\hline 3 & Che Sidik & $\begin{array}{c}\text { Songket } \\
\text { dealer } \\
\text { house }\end{array}$ & $\begin{array}{c}\text { Family } \\
\text { activities, } \\
\text { resting, } \\
\text { sleeping }\end{array}$ & $\begin{array}{c}\text { Rumah } \\
\text { ibu }\end{array}$ & $\begin{array}{c}\text { Calli- } \\
\text { grap } \\
\text { hy }\end{array}$ & $\begin{array}{l}\text { Ventilation } \\
\text { panel on top } \\
\text { of doors }\end{array}$ & $\begin{array}{c}\text { direct } \\
\text { piercing } \\
\text { without } 3 \mathrm{D} \\
\text { incision } \\
\text { (tebuk } \\
\text { tembus tanpa } \\
\text { silat) }\end{array}$ & Religion & $\begin{array}{c}\text { Religious } \\
\text { and } \\
\text { exemplary }\end{array}$ \\
\hline
\end{tabular}

This shows two new findings, firstly the principle of form follows function has long been adopted in the design of Malay houses before the principle was introduced and developed in Europe, which confirms that the Malay architecture first understands and deepens the meaning of form follows function that is followed by the modernists in the 20th century.

Secondly, the principle of form follows function in the Malay heritage house where there is a symbolism element. This element is more about the science of sustainable education and the formation of personality to maintain harmony among fellow humans which is not been found in Louis Sullivan's principle approach.

\section{CONCLUSION}

The study found that the motifs found in the main spaces of Malay heritage houses were in line with the principle of form follows function. In addition, the study proved that every motif was implicitly chosen in line with the function of the space and the background of the occupants. The study also concluded that the principle of form follows function has long been practiced before it was introduced by the Western architecture. It is hoped that this study will contribute to the development of the identity of the still unknown national architecture

\section{REFERENCES}

1. B. S. B. R. A. Shah,. The Terengganu Timber Malay House. Petroliam Nasional Berhad by Badan Warisan Malaysia, 1988

2. P. Oliver, Encyclopedia of Vernacular Architecture of the World. England: Cambridge University Press, 1997.

3. Y. R. Chen, S. I. Ariffin, and M. H. Wang, "The typological rule system of Malay houses in Peninsula Malaysia," Journal of Asian Architecture and Building Engineering, 7(2), 2008, pp. 247-254.

4. S. I. Ariffin, Order in traditional malay house form. $\mathrm{PhD}$ thesis, England: Oxford Brookes University, 2001.
5. Karsam, Seni ukiran Jepara Indonesia: Kajian ciri dan motif. Master thesis, Kuala Lumpur: Universiti Malaya, 1999.

6. A. H. Nasir, Traditional Malay Wood Carving. Kuala Lumpur: Dewan Bahasa dan Pustaka, 1987.

7. Z. Kamarudin and I. Said, "Composition of Malay woodcarving: Case studies on two traditional timber houses," Jurnal Alam Bina, 2, 2008, pp. 101-118.

8. M. A. Yahya, Simbolisme dalam Seni Bina Rumah Melayu Kelantan. Kuala Lumpur: Dewan Bahasa dan Pustaka, 1995.

9. A. H. Nasir, The Traditional Malay House. Kuala Lumpur: Malaysian Institute of Translation and Books (ITBM), 2011.

10. S. Ahmad, M. Z. Mohd Taib, and M. Masri, "Istana Besar Tengku Long: Wall carving decoration and motifs influences the spatial social interaction at Surung area," 9th Regional Symposium of the Malay Archipelago, 2012, pp. 1-14.

11. A. A. Bakar, Motif-motif yang menghiasi rumah tiang dua belas di Kelantan dan Terengganu. Master thesis, Selangor: Universiti Kebangsaan Malaysia, 2014.

12. S. Fadzil, Islam dalam Sejarah dan Kebudayaan Melayu. Selangor: Universiti Kebangsaan Malaysia, 1999. 